\title{
Optimalisasi Kinerja Amil Melalui Budaya, Kreativitas, Sarana Prasarana dan Kepercayaan Pada Lembaga Amil Zakat (LAZ) di Kota Pekanbaru
}

\author{
JHONNY ARDAN MARDAN \\ Akademi Keuangan dan Perbankan Riau (AKBAR) \\ Jln. HR. Subrantas 57 Panam Pekanbaru 28293 Telp. (0761) 63237 \\ E-mail : akbar_stier@yahoo.com
}

\begin{abstract}
Issues raised in this study is the performance of the Institute Amil Zakat Zakat (LAZ) in Pekanbaru. The variables of this research is the influence of Organizational Culture, Creativity, Infrastructure and Communities Trust (the independent variable) and Amil performance (the dependent variable). The purpose of this study is to identify and analyze (1) the influence of the Influence of Organizational Culture Performance Amil, (2) the effect on the performance of Amil Creativity, (3) the effect on the performance of Amil Infrastructure, (4) the effect of Societies Trust Amil performance, (5) and the influence of Organizational Culture, Creativity, and Faith Community Infrastructure jointly on the performance of Amil. Object of this study is four Institute Amil Zakat (LAZ) are located in the city of Pekanbaru, LAZ Swadaya Ummah, LAZ Rumah Zakat, LAZIS Muhammadiyah and LAZNAS Chevron Rumbai, the number of Amil Zakat at 157 persons. The method used in this study is a quantitative method, and the entire sampling technique using proportional stratified random sampling technique. The results showed that the $t$ value of 2.015 organizational culture variables is greater than t table $(\alpha / 2, n-2)=2.000$ means $(2.015>2.000=H o$ is rejected). For creativity variables $(2.605>2.000=$ Ho rejected) means no influence on the performance of amyl creativity. T value of infrastructure variables $(2.038>2.000=\mathrm{Ho}$ rejected) no effect on the performance of amyl infrastructure. Last on the trust variables $(2.178>2.000=$ Ho rejected) no effect on the performance of amyl confidence. Then the variable Organizational Culture, Creativity and Infrastructure and the trust jointly significant effect on the performance of the Institute Amil Amil Zakat (LAZ) in Pekanbaru which is equal to 0.507 or $50.7 \%$.
\end{abstract}

Keywords: Culture, Creativity, facilities and infrastructure, trust, performance Amil.

Zakat merupakan bentuk dari kepedulian umat terhadap sesamanya yang seagama dan seiman dan merupakan perwujudan dari keadilan sosial di tengah-tengah masyarakat. Oleh karena begitu pentingnya persoalan zakat ini sebagai suatu kewajiban seorang muslim, sehingga kata zakah dalam bentuk ma'rifah (definisi) disebut tiga puluh tiga kali di dalam Al-Quran, diantaranya dua puluh tujuh kali disebutkan dalam satu ayat bersama shalat, dan hanya satu kali disebutkan dalam konteks yang sama dengan shalat tetapi tidak dalam satu ayat, yaitu firman Allah SWT: "Dan orang-orang yang giat menunaikan zakat, setelah ayat: "Orang-orang yang khusyu' dalam shalat." (Al-Qaradhawiy, 2004:39). Zakat adalah satu dari rukun Islam yang sangat memerlukan pemikiran semua muslim untuk dikelola dengan baik. Apabila zakat dikelola dan dimenej dengan baik dapat dipastikan zakat dapat dijadikan sebagai alat pembangunan ekonomi yang cukup ampuh untuk mengikis jumlah kemiskinan di muka bumi ini. Zakat merupakan salah satu potensi ekonomi umat Islam yang ampuh untuk membangun ekonomi umat dan dapat menjauhkan umat islam dari kemiskinan dan kebodohan serta mampu meningkatkan taraf hidup umat menuju umat yang sejahtera lahir dan batin.

Mengenai potensi zakat di Indonesia, ada banyak pendapat terkait dengan hal ini. Setiap pihak memberikan prediksi dan ekspetasi masing-masing. Sebagaimana yang dipaparkan oleh Sudewo (Republika, 2006) tentang Buaian Potensi Zakat. Pendapat pertama berasal dari 
mantan Menteri Agama, Said Agil Munawar yang menyatakan potensi zakat Rp. 7 Trilyun per tahun. Pendapat kedua, PIRAC (Public Interest Research and Advocacy Center) memprediksi bahwa potensi nilai zakat sebesar Rp. 9 Trilyun per tahun. Pendapat yang ketiga berasal dari Pusat Budaya dan Bahasa UIN Syarif Hidayatullah Jakarta yang menegaskan bahwa perolehan zakat bisa mencapai Rp. 19 Trilyun per tahun. Sementara itu, menurut Sudewo sendiri, dengan menggunakan angka jumlah penduduk dan melakukan simulasi terhadap jumlah penduduk muslim yang kaya mencoba melakukan proyeksi terhadap tiga skenario potensi. Skenario pertama, potensi zakat sebesar Rp. 10,8 Trilyun per bulan. Skenario kedua potensi zakat mencapai Rp. 21,6 Trilyun dan skenario ketiga potensi zakat sebesar 32,4 Trilyun. Perkiraan potensi lainnya dilakukan oleh Nasution (2006), dengan menggunakan data GDP (Gross Domestic Product) Indonesia dan dengan asumsi bahwa penguasaan aset umat muslim sebesar 20\% dari total GDP dan besaran zakat sebesar $2,5 \%$ maka potensi zakat adalah sebesar Rp. 7,5 hingga 8,7 Trilyun rupiah.

Berikutnya berdasarkan hasil penelitian Badan Amil Zakat Nasional (BAZNAS) dan Islamic Development Bank (IDB) pada tahun 2011, terjadi kenaikan potensi zakat di Indonesia sebesar Rp. 217 Trilyun atau 3,14\% dari GDP (Gross Domestic Product) Indonesia. Di Indonesia, pengelolaan zakat dilaksanakan oleh Badan Amil Zakat (BAZ) dan Lembaga Amil zakat (LAZ). BAZ adalah badan amil zakat yang dibentuk pemerintah, untuk tingkat nasional BAZ dibentuk oleh Presiden atas usul menteri, di tingkat propinsi dibentuk oleh gubernur atas usul kepala kantor wilayah Departemen Agama propinsi, di tingkat kabupaten atau kota dibentuk oleh bupati atau walikota atas usul kepala kantor Departemen Agama kabupaten atau kota, dan di tingkat kecamatan BAZ dibentuk oleh camat atas usul kepada kantor agama kecamatan (UU Zakat No 38 tahun 1999).
Sementara LAZ adalah lembaga yang dibentuk masyarakat yang memiliki tugas pengumpulan, pendistribusian dan pendayagunaan dana zakat. Pengelolaan dana zakat di Indonesia telah diatur dalam Undang-Undang Zakat nomor 38 tahun 1999, dan disempurnakan oleh UndangUndang (UU) Pengelolaan Zakat nomor 23 tahun 2011. BAZ dan LAZ memiliki otoritas untuk mengelola zakat dan telah diatur dalam UU zakat tersebut. Menurut UU Zakat nomor 23 tahun 2011 yang dimaksud pengelolaan zakat adalah kegiatan yang meliputi perencanaan, pengorganisasian, pelaksanaan dan pengawasan terhadap pendistribusian serta pendayagunaan zakat. Tujuan besar pengelolaan zakat adalah, pertama, meningkatnya kesadaran masyarakat dalam penunaian dan pelayanan ibadah zakat. Kedua, meningkatnya fungsi dan peranan pranata keagamaan dalam upaya mewujudkan kesejahteraan masyarakat dan keadilan sosial. Ketiga, meningkatnya hasil guna dan daya guna zakat.

Secara umum Lembaga Pengelola Zakat (LPZ) memainkan tiga fungsi utama yaitu pengumpul zakat, pengelola zakat dan penyalur dana zakat. LPZ sebagai pengumpul dana zakat dari pembayar zakat (muzakki). Manajemen zakat modern menuntut agar para petugas (amil) zakat mengambil dana zakat dari muzakki. Aries Mufti dan M. Syakir Sula (2009:92) mengungkapkan bahwa diantara tugas pokok LPZ adalah meningkatkan kesadaran umat untuk berzakat dan menjangkau muzakki seluas-luasnya. Di dalam UU zakat pun belum ada penjelasan mengenai sanksi bagi seorang muslim yang tidak membayar zakat.

Oleh karena itu, LAZ harus aktif menjemput dana zakat, aktif menjalin komunikasi yang harmoni kepada para pembayar zakat. LAZ dituntut melakukan kegiatan promosi dan pemasaran zakat secara masif melalui program-program kegiatan yang menarik. Seperti ceramah, seminar, workshop, iklan di media masa dan cetak, pameran, poster, silaturahim, 
sosial media, dan lain-lain. Diharapkan melalui program strategis tersebut terjadi peningkatan penghimpunan dana zakat. LPZ sebagai penyalur dana zakat bermaksud bahwa BAZ ataupun LAZ berkewajiban menyalurkan dana zakat yang terhimpun kepada delapan golongan penerima zakat, sebagaimana yang telah Allah SWT sebutkan di dalam al Quran surah al-Taubah ayat 60: "Sesungguhnya zakat-zakat itu hanyalah untuk orang-orang fakir, orang-orang miskin, pengurus-pengurus zakat, para muallaf yang dibujuk hatinya, untuk (memerdekakan) budak, orang-orang yang berutang, untuk jalan Allah, dan orang-orang yang sedang dalam perjalanan, sebagai suatu ketetapan yang diwajibkan Allah, dan Allah Maha Mengetahui lagi Maha Bijaksana.“

Delapan golongan penerima zakat ini biasa disebut dengan mustahik zakat. Penyaluran dana zakat dilakukan melalui program penyaluran zakat secara konsumtif dan produktif. Menurut kebijakan Badan Amil Zakat Nasional (BAZNAS) program penyaluran dana zakat terdiri atas 5 program, yaitu program kemanusiaan, kesehatan, pendidikan, ekonomi dan dakwah.

Berdasarkan data Badan Pusat Statistik (BPS) wilayah Riau jumlah penduduk miskin di kota Pekanbaru mulai tahun 2009 hingga 2011 mengalami peningkatan. Pada tahun 2009 penduduk miskin di Pekanbaru sebesar 867.239 orang $(3,29 \%)$, tahun 2010 penduduk miskin sebanyak 897.767 (4,20\%), dan pada tahun 2011 sebesar $930.215(3,45 \%)$. Berdasarkan data ini pemerintah daerah dan masyarakat mengharapkan kinerja Lembaga Amil Zakat (LAZ) di kota Pekanbaru untuk membantu kaum dhu'afa melalui dana zakat.

Komitmen penghimpunan dana zakat oleh Lembaga Amil Zakat (LAZ) di Kota Pekanbaru juga masih sangat rendah. Berikut data penghimpunan dana zakat, infak dan sedekah (ZIS) oleh Lembaga Amil Zakat (LAZ) kota Pekanbaru bahwa capaian penghimpunan zakat di kota Pekanbaru yakni berasal dari lembaga amil zakat antara lain: Swadaya Ummah, Rumah Zakat, Chevron Rumbai dan LAZIS Muhammadiyah, diketahui bahwa capaian mengalami penurunan dari tahun 2010 ke 2011 mencapai $23,47 \%$ menurun menjadi $9,94 \%$ di tahun 2012.

Kemudian dilihat dari fenomena lainnya dari hasil pengamatan lapangan diperoleh informasi sebagai berikut: 1) LAZ hanya konsentrasi kepada bayaran zakat fitrah dan tidak pada zakat harta. 2) Masih menganut cara tradisional dalam menghimpun zakat, yaitu menunggu pembayar zakat di kantor. 3) Lemahnya seruan berzakat secara langsung yang meluas dan agresif kepada masyarakat. 4) Lemahnya promosi untuk kesadaran berzakat bagi umat. 5) Kekurangan karyawan yang profesional dan terlatih. 6) Kekurangan kemudahan sarana dan prasana dan saluran pembayaran zakat. 7) Lemahnya inovasi dan kreasi dalam pengelolaan dana zakat. 8) Kurangnya kepercayaan masyarakat memberikan zakatnya kepada LAZ dan BAZ.

Berdasarkan uraian pada latar belakang masalah tersebut, dapat diketahui bahwa adanya permasalahan pada kinerja amil zakat dalam rangka penghimpunan dana zakat di masyarakat khususnya masyarakat di Kota Pekanbaru. Apa saja faktor yang mempengaruhinya? Apakah faktor budaya organisasi yang mempengaruhinya? Apakah faktor sarana dan prasana dan kreativitas amil mempengaruhinya? Atau faktor kepercayaan masyarakat menjadi faktor utamanya? Jadi hal inilah yang membuat penulis tertarik melakukan penelitian lebih lanjut dalam sebuah judul: Pengaruh Budaya Organisasi, Kreativitas, Sarana Prasarana dan Kepercayaan Masyarakat Terhadap Kinerja Amil Pada Lembaga Amil Zakat (LAZ) di Kota Pekanbaru.

Menurut Mulyasa

(2004)

menjelaskan bahwa kinerja atau performasi dapat diartikan sebagai prestasi kerja, pelaksanaan kerja, pencapaian kerja, hasil kerja atau unjuk kerja. Menurut Ibnu Katsir (1998:265) perintah zakat telah diwajibkan pada tahun kedua Hijriyah ketika Rasulullah SAW berada di Madinah. Menurut kamus Lisan al-'Arab, Ibnu 
Manzhur (1968:358-359) Kata zakah merupakan bentuk mashdar, kata dasarnya adalah zakaa, yang berarti: tumbuh dan berkembang (namaa), suci (thaharah), berkah (barakah), baik dan bagus (salaha), memuji (madaha), halal.

Sedangkan zakat secara terminologi, ulama fikih berbeda pendapat. Menurut ulama Syafi'i zakat adalah nama bagi sesuatu yang dikeluarkan dari harta atau institusi, dengan sifat tertentu dan untuk golongan tertentu. Ulama Hanafi mendefinisikan zakat yaitu menjadikan hak milik kadar tertentu, dari harta tertentu, kepada golongan tertentu yang telah ditetapkan syariat. Sementara ulama Maliki berpendapat bahwa zakat adalah mengeluarkan kadar tertentu dari harta tertentu yang telah sampai nisab, dan diserahkan kepada golongan tertentu. Adapun ulama Hanbali mengungkapkan zakat adalah hak wajib ke atas harta tertentu, untuk golongan yang tertentu dan pada waktu yang tertentu. (al- Jaziriyy, 2000:50).

Dari beberapa definisi zakat di atas, penulis menyimpulkan bahwa zakat adalah mengeluarkan harta dari individu atau institusi, dengan jumlah tertentu, diserahkan kepada golongan tertentu pada waktu tertentu.

Dimensi kinerja menurut Wirawan (2009:53) Dimensi kinerja karyawan dalam melaksanakan pekerjaan yang menunjukkan kinerja adalah sebagai berikut: Hasil Kerja, adalah keluaran kerja dalam bentuk barang dan jasa yang dihitung dan diukur kuantitas dan kualitasnya. Perilaku kerja, seorang karyawan memiliki dua perilaku yaitu: perilaku pribadi dan perilaku kerja. Perilaku kerja adalah yang berhubungan dengan pekerjaan seperti kerja keras , ramah terhadap pelanggan, dan cara berjalan. Sifat pribadi yang berhubungan dengan pekerjaan yang dibawa sejak lahir dan diperoleh ketika dewasa dari pengalaman kerjanya, misalnya pemberani, tega, pembersih, ceria.

Pengertian budaya organisasi menurut Fred Luthans (2005) budaya organisasi adalah tata nilai \& norma yang menuntun perilaku jajaran organisasi. Gupta dan Govindarajan (2000) mengemukakan sebuah kerangka dimana budaya organisasi mempunyai enam komponen yaitu struktur organisasi, sistem maklumat, individu, sistem ganjaran, kepimpinan dan proses. Lembaga Amil Zakat sebagai organisasi mempunnyai komponen organsisai yang terdiri komponen material (orang, sarana prasarana) sedang komponen inmaterial adalah sistem yang ditetapkan dan harus di patuhi seluruh anggota organisasi.

Budaya organisasi di tinjau dari aspek pengetahuan suatu pengetahuan bersama dalam organisasi, anggota organisasi saling berbagi pengetahuan untuk mejwujudkan tujuan bersama. Budaya mendukung saling berbagi pengetahuan antara anggota organisasi dan menggunakan pengetahuan yang ada untuk menghadapi segala masalah, di mana saja dan waktu kapan saja. Menurut Al-Alawi et al. (2007) melihat komponen budaya organisasi yang mempengaruhi saling berbagi pengetahuan. Mc Dermot dan O'Dell (2001) telah melaksanakan penelitian untuk mengetahui apakah budaya organisasi mempengaruhi tahap berbagi pengetahuan.

Pendapat lain tentang budaya organisasi yaitu: budaya organisasi adalah apa yang dipersepsikan karyawan dan cara persepsi itu menciptakan suatu pola keyakinan, nilai, dan ekspektasi (Ivancevich, dkk, 2006). Greenberg et al (2003), yakni budaya organisasi merupakan suatu kerangka kerja kognitif yang terdiri dari sikap, nilai, norma prilaku, dan pengharapan yang dianut oleh setiap anggota organisasi budaya organisasi juga dianggap sebagai suatu sistem yang dianut bersama oleh semua anggota organisasi yang dapat membedakan suatu organisasi dengan organisasi lainnya.

Menurut Fred Luthans (2005) budaya organisasi adalah tata nilai \& norma yang menuntun perilaku jajaran organisasi. Sedangkan Heathfield (2006) menyatakan seperti halnya budaya organisasi pada umumnya, budaya organisasi sekolah dibangun oleh seluruh pengalaman hidup, nilai-nilai, keyakinan, asumsi-sumsi dasar, 
sikap dan perilaku yang dihayati secara bersama.

Kreativitas adalah kemampuan individu dalam memunculkan suatu gagasan baru mencapai sesuatu terutama dari apa yang sudah diketahui, Ernie dan Kurniawan (2010). Kreativitas adalah seseorang yang hampir secara rutin menghasilkan hasil kreatif (Perkins, 1988). Menurut Suryana (2003) menyatakan bahwa kreativitas adalah: Berpikir sesuatu yang baru. Kreativitas sangat diperlukan dalam organisasi sebagai bagian dari kemampuan organisasi untuk terus beradaptasi dengan perubahan, Ernie dan Kurniawan (2010).

Dimensi kreativitas yang digunakan dalam penelitian ini menurut Sutrisno (2010: 111) antara lain: Nilai-nilai intelektual dan artistik; merupakan gambaran kemampuan intelektualitas dan seni dari seorang karyawan dalam menghasilkan produk yang baik. Ketertarikan pada kompleksitas; Merupakan keinginan yang dirasakan untuk dapat diwujudkan oleh karyawan dalam bekerja. Kepedulian pada pekerjaan dan pencapaian; merupakan bentuk nilai capaian akan keberhasilan bagi seorang karyawan. Ketekunan; merupakan bentuk kerja keras dalam menghasilkan hasil kerja yang optimal. Pemikiran yang mandiri; merupakan kemampuan dalam menghasilkan hal yang baru yang berguna untuk menyelesaikan pekerjaan seperti idea tau gagasan. Otonom; merupakan wujud karyawan yang berdiri sendiri dalam menghasilkan produk bukan tergantung pada pihak lain. Peraya diri; merupakan sikap keyakinan yang mantap akan hasil kerja untuk diwujudkan. Kesiapan mengambil resiko; merupakan bentuk usaha tampil beda dalam mencapai tujuan.

Mulyasa (2004: 49) menyatakan sarana adalah peralatan dan perlengkapan yang secara langsung dipergunakan dan menunjang proses. Seperti gedung, ruang, meja kursi, serta alat-alat dan media. Adapun yang dimaksud dengan prasarana adalah fasilitas yang secara tidak langsung menunjang jalannya proses, seperti halaman, kebun, taman, jalan, tetapi jika dimanfaatkan secara langsung. Sutjipto dan Kosasi (2004:
170) menyatakan prasarana dan sarana adalah semua benda bergerak maupun yang tidak bergerak, yang diperlukan untuk menunjang penyelenggaraan sebuah proses, baik secara langsung maupun tidak langsung.

Imron (2003:86) menyatakan sarana adalah semua perangkat peralatan, bahan, dan perabot yang secara langsung digunakan dalam proses. Sarana dapat ditinjau dari habis tidaknya dipakai, kemudian ditinjau dari bergerak tidaknya dan ditinjau dari hubungannya dengan proses. Sedangkan prasarana adalah semua perangkat kelengkapan dasar yang secara tidak langsung menunjang pelaksanaan proses. Prasarana ini terdiri dari ruang teori, perpustakaan, ruang praktek, laobratorium yang merupakan prasarana yang langsung berhubungan dengan kegiatan kerja. Sedangkan yang tidak langsung berhubungan dengan aktivitas antara lain ruang kantor, kantor, tanah dan jalan, kamar kecil dan tempat parkir kendaraan.

$$
\text { Menurut Rohiat (2009:26) }
$$

manajemen sarana prasarana adalah kegiatan yang mengatur untuk mempersiapkan segala peralatan/material bagi terselenggaranya suatu proses. Ia mencakup segala proses perencanaan pengadaan, pendayagunaan dan pengawasan sarana prasarana yang digunakan agar mencapai tujuan. Dimensi yang digunakand alam mengukur sarana dan prasarana menurut Mulyasa (2004: 49) dimensi sarana prasarana sebagai berikut: Sarana; gedung, ruang, meja kursi, serta alat-alat dan media, transportasi, komunikasi. Prasarana; halaman, kebun, taman, jalan, akses jalan, akses internet, akses perbankan

$$
\text { Ba dan Pavlou (2002) }
$$

mendefinisikan trust adalah penilaian hubungan seseorang dengan orang lain yang akan melakukan transaksi tertentu menurut harapan orang kepercayaannya dalam suatu lingkungan yang penuh ketidak-pastian. Kepercayaan adalah kemauan seseorang untuk bertumpu pada orang lain dimana kita memiliki keyakinan 
padanya. Kepercayaan merupakan kondisi mental yang didasarkan oleh situasi seseorang dan konteks sosialnya. Ketika seseorang mengambil suatu keputusan, ia akan lebih memilih keputusan berdasarkan pilihan dari orang- orang yang lebih dapat ia percaya dari pada yang kurang dipercayai (Moorman dalam Zainuddin, 2012)

Dimensi yang digunakan untuk mengukur kepercayaan adalah menurut Safri Nur Mantu (2007:136) menyatakan bahwa kepercayaan dapat dilihat dari. Substansi dan formalitas janji yang telah disampaikan selalu dapat dipenuhi. Isi janji selalu dapat memuaskan dalam arti bahwa janji yang ditunaikan sesuai denga yang seharusnya.

Menurut Mulyasa (2004) menjelaskan bahwa kinerja atau performasi dapat diartikan sebagai prestasi kerja, pelaksanaan kerja, pencapaian kerja, hasil kerja atau unjuk kerja. Menurut Ibnu Katsir (1998:265) perintah zakat telah diwajibkan pada tahun kedua Hijriyah ketika Rasulullah SAW berada di Madinah. Menurut kamus Lisan al'Arab, Ibnu Manzhur (1968:358-359) Kata zakah merupakan bentuk mashdar, kata dasarnya adalah zakaa, yang berarti: tumbuh dan berkembang (namaa), suci (thaharah), berkah (barakah), baik dan bagus (salaha), memuji (madaha), halal.

\section{METODE}

Objek penelitian ini adalah empat Lembaga Amil Zakat (LAZ) yang terdapat di kota Pekanbaru, yaitu LAZ Swadaya Ummah, LAZ Rumah Zakat, LAZIS Muhammadiyah dan LAZNas Chevron Rumbai, dengan jumlah Amil (petugas) Zakat sebanyak 157 orang. Metode penelitian yang digunakan dalam penelitian ini adalah metode kuantitatif, dan pengambilan sampel dengan menggunakan teknik proporsional stratified random sampling.

\section{HASIL}

Hasil pengujian coeficient seperti disajikan pada tabel di atas menunjukkan bahwa nilai persamaan regresi berganda yang dihasilkan sebagai berikut:

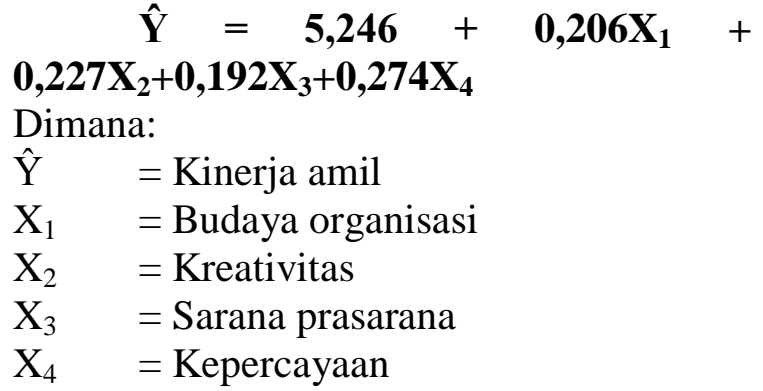

Pengertian dari persamaan tersebut adalah:

a. Konstanta sebesar 5,246 menyatakan bahwa jika tidak ada variabel Budaya Organisasi, Kreativitas dan Sarana Prasarana dan kepercayaan maka nilai kinerja amiol adalah sebesar 5,246 satuan.

b. Koefisien regresi X1 sebesar 0,206 menyatakan bahwa setiap penambahan (karena tandanya + ) satu satuan variabel budaya organisasi maka akan meningkatkan kinerja amil sebesar 0,206 satuan.

c. Koefisien regresi X2 sebesar 0,227 menyatakan bahwa setiap penambahan (karena tandanya +) satu satuan variabel kreativitas maka akan meningkatkan kinerja amil sebesar 0,227 satuan.

d. Koefisien regresi X3 sebesar 0,192 menyatakan bahwa setiap penambahan (karena tandanya + ) satu satuan variabel sarana prasarana maka akan meningkatkan kinerja amil sebesar 0,192 satuan.

e. Koefisien regresi X4 sebesar 0,274 menyatakan bahwa setiap penambahan (karena tandanya +) satu satuan variabel kepercayaan maka akan meningkatkan kinerja amil sebesar 0,274 satuan.

\section{PEMBAHASAN}

Berdasaarkan hasil pengujian hipotesis yang dilakukan, terbukti bahwa secara parsial variabel Budaya Organisasi berpengaruh terhadap kinerja amil pada Lembaga Amil Zakat (LAZ) di Kota Pekanbaru; Kreativitas berpengaruh terhadap kinerja amil pada Lembaga Amil Zakat (LAZ) di Kota Pekanbaru; Sarana 
Prasarana berpengaruh terhadap kinerja amil pada Lembaga Amil Zakat (LAZ) di Kota Pekanbaru; dan kepercayaan berpengruh berpengaruh kinerja amil pada Lembaga Amil Zakat (LAZ) di Kota Pekanbaru dan secara simultan Budaya Organisasi, Kreativitas dan Sarana Prasarana dan kepercayaan berpengaruh terhadap kinerja amil pada Lembaga Amil Zakat (LAZ) di Kota Pekanbaru.

\section{Pengaruh budaya organisasi terhadap kinerja amil pada Lembaga Amil Zakat (LAZ) di Kota Pekanbaru}

Temuan penelitian menunjukkan bahwa ada pengaruh budaya organisasi terhadap kinerja amil. Terbukti bahwa budaya organisasi berpengaruh positif dan signifikan terhadap kinerja amil. Dari analisis data menunjukkan bahwa Lembaga Amil Zakat berprinsip berani mengambil resiko dalam pengumpulan dana zakat, kemudian Lembaga berusaha maksimal dalam penghimpunan dana zakat dan pengurus selalu terus belajar dalam meningkatkan ilmu pengetahuan tentang fund raising zakat. Sehingga amil memberikan pelayanan dengan ramah terhadap muzakki, Amil melakukan sosialisasi kepada masyarakat akan pentingnya zakat dan amil melakukan pendataan pembayar zakat (muzakki) setiap periode.

Kemudian nilai yang terendah dari budaya organisasi LAZ antara lain masih rendahnya fleksibelitas amil terhadap perubahan zaman yang mana amil masih kaku menggunakan teknologi informasi, masih rendah menggunakan media sosial dalam rangka promosi zakat, rendahnya program-program strategis yang menarik dalam penghimpunan dana zakat. Padahal dalam al-Quran dan hadits yang merupakan referensi utama dalam pelaksanaan zakat menunjukkan adanya perintah kepada para amil untuk aktif, inovatif dan kreatif dalam rangka menjemput zakat kepada para pembayar zakat. Diperlukan programprogram strategis dalam fund rising dana zakat, amil tidak boleh kaku dan menunggu datangnya zakat, namun harus diambil dan dijemput dari tangannya muzakki.

Kemudian masih rendahnya penggunaan amil yang kompeten, hal ini dapat dilihat bahwasannya rekrutmen sebagai amil dilaksanakan belum berdasarkan kebutuhan pekerjaan, sehingga amil yang bekerja adalah mereka-mereka yang hanya modal keinginan saja. Masih rendahnya rekrutmen amil yang kompeten berdampak pada kerja dan kinerja. Diperlukan masa adabtasi bagi amil baru yang cukup lama.

Terkait dengan kompetensi amil, masih terlihat amil yang bekerja tidak meluangkan waktu penuh untuk mengelola Lembaga Zakat, masih ada yang menggunakan waktu sisanya untuk mengelola dana zakat. Sehingga berdampak pada kerja dan kinerja.

Hasil penelitian ini juga didukung oleh pendapat Rani Mariam (2009) pengaruh budaya organisasi terhadap kinerja pegawai adalah signifikan dan positif. Kemudian hasil penelitian Sri Porwani (2010) menunjukkan bahwa budaya organisasi memiliki pengaruh positif dan signifikan terhadap kinerja karyawan. Selanjutnya hasil penelitian Nono Sukardi (2012) budaya organisasi mempunyai pengaruh positif dan signifikan secara simultan terhadap kinerja pegawai. Hasil penelitian Sulistyaningsih dkk (2012) analisis yang dilakukan dengan menggunakan teknik analisis Pearson Product Moment, diperoleh budaya organisasi mempunyai hubugan positif terhadap kinerja. Hasil penelitian Rani Mariam (2009) pengaruh dari budaya organisasi terhadap kepuasan kerja adalah signifikan dan positif.

\section{Pengaruh kreativitas terhadap kinerja amil pada Lembaga Amil Zakat (LAZ) di Kota Pekanbaru}

Hasil perhitungan untuk variabel kreativitas menunjukkan adanya pengaruh krativitas terhadap kinerja amil. Hal ini terlihat bahwa amil menggunakan nilai 
artistik (lemah lembut) dalam mengajak masyarakat dan amil selalu mengedepankan nilai intelektual dalam menjalankan kegiatannya memberikan pengaruh terhadap kinerja amil dalam memberikan pelayanan dengan ramah terhadap muzakki, amil melakukan sosialisasi kepada masyarakat akan pentingnya zakat dan amil melakukan pendataan pembayar zakat (muzakki) setiap periode.

Dilihat dari kreativitas amil dalam melaksanakan penghimpunan dana zakat, masih dilihat rendahnya sikap mandiri dan independen dalam melaksanakan tugasnya. Masih terlihat ketidaksamaan pandangan dan kebijakan antara amil yang berada pada level operasional dengan amil level pengambil keputusan, sehingga membuat amil tidak mandiri dan independen dalam berfikir dan bertindak sesuatu yang baru. Misalnya pada LAZNas Chevron Rumbai, antara pengurus amil yang berada pada posisi pengambil kebijakan berbeda pandangan dengan amil yang berada di level operasional. Perbedaan memahami konsep dan realita di lapangan. Hal ini juga terjadi di LAZIS Muhammadiyah. Sikap mandiri dan independen ini dapat dipengaruhi oleh faktor internal organisasi LAZ, seperti perbedaan pandangan antar pengurus amil zakat, dan ekternal organisasi LAZ seperti peraturan pemerintah mengenai zakat.

Rendahnya kemandirian dan independen ini dapat berdampak pada amil yang rendah kemampuan untuk selalu tampil beda dalam mencapai tujuan. Tampil beda berarti memiliki ciri khas dan nilai tambah sebagai identitas unik yang melekat di Lembaga Zakat tersebut. Peneliti belum melihat nilai tambah pada keempat LAZ yang menjadi objek penelitian.

Hasil penelitian ini sejalan dengan penelitian tentang pengaruh kreativitas terhadap kinerja dalam penelitian Eddy Poernomo (2006) menunjukkan bahwa kreativitas berpengaruh terhadap kinerja manajer.

\section{Pengaruh sarana prasarana terhadap kinerja amil pada Lembaga Amil Zakat (LAZ) di Kota Pekanbaru}

Hasil penelitian ini menunjukkan adanya pengaruh Sarana prasarana terhadap kinerja Amil. Hal ini dapat dilihat dari ketersediaan sarana prasarana seperti lembaga memiliki kelengkapan meja dan kursi kerja untuk menunjang kegiatan zakat dan lembaga memiliki kebijakan mutu dalam penghimpunan dana zakat. Lembaga memiliki alat komunikasi untuk kegiatan penghimpunan, menyediakan transportasi, memiliki akses perbankan dalam melakukan transaksi. Hal ini berpengaruh terhadap kinerja amil dalam memberikan pelayanan dengan ramah terhadap muzakki, dan melakukan sosialisasi kepada masyarakat akan pentingnya zakat serta melakukan pendataan pembayar zakat (muzakki) setiap periode.

Yang menjadi persoalan mengenai sarana prasarana LAZ dalam melaksanakan penghimpunan zakat adalah LAZ belum memiliki ketersediaan gedung yang representativ, dapat diketahui gedung LAZ Rumah Zakat berada di ruko dengan keterbatasan areal parkir, kemudian juga pada LAZIS Muhammadiyah gedung masih menumpang dan areal parkir yang terbatas, dan LAZNas Chevron Rumbai gedung masih menumpang dalam komplek CPI, dengan akses masuk ke kantor yang sulit dan sangat prosuderal.

Berikutnya yang menjadi persoalan juga mengenai akses internet yang cepat dan lancar. Jaringan internet yang tidak lancar dapat mempengaruhi kinerja amil berupa rendahnya pelayanan kepada muzakki yang senantiasa menggunakan internet dan komputer. Informasi dan laporan dapat disampaikan melalui email dan website LAZ yang hal ini sangat didukung dengan adanya jaringan internet yang lancar.

Perizinan dan legalitas juga menjadi masalah, yaitu LAZNas Chevron Rumbai belum mendapatkan legalitas dari Kementrian Agama Republik Indonesia 
sebagai LAZ yang diakui. Namun, pemerintah masih memberikan waktu tenggang untuk mempersiapkan semua persyaratan legalitas LAZ oleh Kementrian Agama hingga 2016. Saat ini ke empat LAZ yang ada masih sah dan boleh untuk melakukan kegiatan penghimpunan dan penyaluran zakat. Untuk 3 (tiga) LAZ lainnya telah menerima legalitas dari Kementrian Agama sebagai LAZ yang resmi melaksankan pengelolaan zakat, infak dan sedekah.

Hasil penelitian ini sejalan dengan kajian terdahulu tentang kontribusi sarana prasarana terhadap kinerja dalam penelitian Eko Djatmiko (2006) Sarana Prasarana berpengaruh terhadap kinerja sebesar $36,9 \%$. Sarana prasarana faktor utama pencapaian tujuan organisasi, jika sarana pransana kurang dalam sebuah organisasi maka akan sulit untuk mencapai tujuan organisasi secara baik.

\section{Pengaruh kepercayaan terhadap kinerja amil pada Lembaga Amil Zakat (LAZ) di Kota Pekanbaru}

Hasil perhitungan menunjukkan bahwa kepercayaan berpengaruh terhadap kinerja amil. Hal ini dapat dilihat dari amil memiliki data yang akurat. Data ini dapat berupa data penghimpunan, dan data penyaluran. Masing-masing LAZ telah menggunakan komputer dalam menginput data dalam pengelolaan zakat.

Berikutnya kepercayaan muzakki dapat dilihat dari komunikasi LAZ kepada para pembayar zakat yang telah menyetor zakatnya berjalan baik. LAZ memiliki data muzakki dan senantiasa menyapa muzakki. Melalui komonukasi ini terjalin hubungan silaturahim dan dapat mewujudkan muzakki yang loyal terhadap LAZ. Jika loyalitas muzakki terwujud maka capaian penghimpunan dana zakat akan meningkat.

Hasil penelitian ini menunjukkan bahwa kepercayaan yang diberikan muzakki diemban amil berupa menyampaikan Laporan Pertanggungjawab dana zakat ke media cetak dan amil menyampaikan laporan penghimpunan dan penyaluran kepada muzakki dan masyarakat. Berpengaruh terhadap pelayanan dengan ramah terhadap muzakki, amil melakukan sosialisasi kepada masyarakat akan pentingnya zakat dan amil melakukan pendataan pembayar zakat (muzakki) setiap periode.

Kepercayaan muzakki juga dapat dibangun melalui pelaporan dana zakat yang telah diaudit oleh auditor berlisensi dan independen, dengan ini semakin meyakinkan hati para muzakki untuk menyalurkan zakat. Laporan yang telah diaudit tersebut menujukkan bahwa amil zakat bertanggungjawab terhadap dana zakat yang dikelola.

Persoalan yang dihadapi mengenai kepercayaan muzakki terhadap amil dalam melaksanakan penghimpunan dana zakat adalah kemapuan amil dalam mengelola dana zakat masih dinilai rendah, dan usaha amil dalam mengajak masyarakat berzakat belum menunjukkan kerja keras yang dapat meningkatkan kepercayaan muzakki. Hal ini berdampak kepada kinerja amil dalam mengumpulkan dana zakat.

Militansi amil dalam mengajak orang membayar zakat masih lemah, hal ini dapat dilihat dari hasil penghimpunan dana zakat masing-masing LAZ dari tahun ke tahun. Pada LAZ Swadayah Ummah dapat dilihat penurunan persentasi penghimpunan dari $71,68 \%$ pada tahun 2011 menurun menjadi $17,58 \%$ di tahun 2012, LAZ Rumah Zakat juga mengalami penurunan persentasi penghimpunan, dari $15,16 \%$ tahun 2011 menurun menjadi 6,52\% pada tahun 2012. LAZNas Chevron Rumbai mengalami hal yang sama dari $-11,08 \%$ pada tahun 2011 turun menjadi $-4,11$ $\%$ pada tahun 2012.

Dalam hal pengelolaan amil terhadap LAZ dinilai masih rendah, hal ini diawali dari rekrutmen amil yang belum berdasarkan kebutuhan kompetensi kerja, pengetahuan amil tentang fikih zakat masih rendah, sehingga amil sulit untuk menentukan besaran dan kadar harta yang dizakatkan. Pelaporan dana zakat yang masih jauh dari standar akuntansi zakat. 
Masalah perbedaan pandangan dan kebijakan di internal pengurus amil juga terkadang berpengaruh dalam pengelolaan zakat.

\section{Pengaruh budaya organisasi, kreativitas dan sarana prasarana serta kepercayaan secara bersama-sama terhadap kinerja amil pada Lembaga Amil Zakat (LAZ) di Kota Pekanbaru}

Hasil uji ANOVA atau $\mathrm{F}$ test dari tabel berikut diperoleh $\mathrm{F}$ hitung lebih besar dibanding dengan $\mathrm{F}$ tabel $(\mathrm{k}-1 ; \mathrm{n}-\mathrm{k}$ atau $4 ; 56)$ $=2,53$. Yaitu $14,404>2,53$ dengan tingkat signifikansi 0,000. Uni Anova ini menyatakan bahwa hipotesis kelima yaitu pernyataan tentang : "Terdapat pengaruh yang signifikan Budaya Organisasi, Kreativitas dan Sarana Prasarana dan kepercayaan secara bersama-sama terhadap kinerja amil pada Lembaga Amil Zakat (LAZ) di Kota Pekanbaru". Karena probabilitas $(0,000)$ jauh lebih kecil dari 0,05 . Artinya hipotesis kelima terbukti, yaitu variabel Budaya Organisasi, Kreativitas dan Sarana Prasarana dan kepercayaan secara bersama-sama berpengaruh signifikan terhadap kinerja amil pada Lembaga Amil Zakat (LAZ) di Kota Pekanbaru. Koefisien determinasi menunjukkan bahwa kontribusi variabel budaya organisasi, kreativitas, sarana prasarana dan kepercayaan terhadap kinerja amil pada LAZ di Kota Pekanbaru. Besarnya kontribusi dapat dilihat dari nilai $\mathrm{R}$ square sebesar 0,507 atau $50,7 \%$. Nilai ini menunjukkan bahwa 50,7\% variabel kinerja amil dapat dijelaskan oleh variabel budaya organisasi, kreativitas, sarana prasarana dan kepercayaan. Kemudian variabel kepercayaan menjadi variabel paling mempengaruhi kinerja amil pada LAZ di Kota Pekanbaru.

Karena kepercayaan kepada amil dalam mengelola dana zakat dan menyalurkannya kepada yang berhak benarbenar sesuai dengan kaedah-kaedahnya, hal ini akan menumbuhkan kepercayaan muzakki dalam mengambil keputusan untuk membayar zakat ke LAZ tersebut.
Kepercayaan menjadi dominan karena hal ini terkait dengan hati, yaitu hati merasa nyaman dan tentram terhadap para amil. Untuk meraih keparcayaan muzakki, maka bagi amil harus mampu dalam skil pengelolaan LAZ, berusaha keras mengajak orang lain berzakat, memiliki data yang akurat, mengadakan acara-acara yang dapat membangun hubungan baik antara LAZ dan Muzakki, senantiasa menyam.paikan laporan pertanggungjawaban dana zakat ke media, muzakki dan masyarakat, dan mampu menggunakan auditor independen dalam pelaporan keuangannya.

Hal ini sesuai dengan apa yang dikatakan Moorman dalam Zainuddin (2012) bahwa kepercayaan adalah kemauan seseorang untuk bertumpu pada orang lain dimana kita memiliki keyakinan padanya. Kepercayaan merupakan kondisi mental yang didasarkan oleh situasi seseorang dan konteks sosialnya. Ketika seseorang mengambil suatu keputusan, ia akan lebih memilih keputusan berdasarkan pilihan dari orang- orang yang lebih dapat ia percaya dari pada yang kurang dipercayai.

\section{SIMPULAN}

Berdasarkan hasil penelitian diketahui bahwa variabel Kepercayaan merupakan variabel yang paling dominan yang mempengaruhi kinerja Amil dalam menghimpun dana zakat di Kota Pekanbaru. Rendahnya kepercayaan muzakki terhadap Amil dalam menghimpun dana zakat berpengaruh terhadap kinerja amil dalam mengelola dana zakat. Hasil penelitian ini berimplikasi kepada kebijakan LAZ dalam meningkatkan kepercayaan muzakki kepada amil melalui rekrutmen amil sesuai dengan kompetensi pekerjaan sehingga amil dapat dipercaya dalam mengelola dana zakat di masa depan.

\section{DAFTAR RUJUKAN}

Aries Mufti dan Muhammad Syakir Sula, "Amanah Bagi Bangsa," Masyarakat 
Ekonomi Syariah, Jakarta, 2009.

Ba, S., and Pavlou, P. A., "Evidence of The Effect of Trust Buliding Technology in Electronic Marrket: Price Premiums \& Buyer Behavior", MIS Quarterly Vol. 26 No. 3, United State, 2002.

Dessler, "Manajemen Personalia", Erlangga, Jakarta, 1992.

Didin Hafidhuddin, 2013, "Potensi Zakat Rp 217 Triliun Terserap Satu Persen", http://www.republika.co.id/ber ita/ekonomi/syariahekonomi/13/04/29/mm039ypotensi-zakat-rp-217-triliunterserap-satu-persen, diakses 24 Oktober 2013.

Eko Djatmiko, "Pengaruh Kepemimpinan Kepala Sekolah Dan Sarana Prasarana Terhadap Kinerja Guru SMP Negeri Kota Semarang", Fokus Ekonomi Vol. 1 No. 2, STIE PENA Semarang, 2006.

Ernie Tisnawati Sule dan Kurniawan Saefullah, "Pengantar Manajemen", Kencana Prenada Media Group, Jakarta, 2010.

Fadelan Fitra Masta, "Peranan Zakat Dalam Peningkatan Kualitas Rumah (Studi Kasus Pada Masyarakat Miskin Penerima Program Bedah Rumah Di Kota Padang)", Tesis Program Pascasarjana Magister Teknik Pembangunan Wilayah Dan
Kota,

Universitas

Diponegoro Semarang, 2010.

Handoko, T Hani, "Manajemen Personalia dan Sumber Daya Manusia”, BPFE Yogyakarta, Yogyakarta, 2001.

Hendri Tanjung dan Nana Minarti, "Kinerja Pengumpulan Zakat Nasional”, Jurnal Iqtishodia, Republika Jakarta, 2012.

Ibn Katsir, "Tafsir al-Quran al- 'Azhim," Dar al-Fikr, Beirut, 1998.

Ibn Manzhur, "Lisan al-'Arab," Dar Beirut, Beirut, 1968.

Imron A., dkk., "Manajemen Pendidikan: Analisis Substantif dan Aplikasinya dalam Institusi Pendidikan", Universitas Negeri Malang, Malang, 2003.

Ivancevich, J.M., Konopaske, R., dan Matteson M.T, "Perilaku dan Manajemen Organisasi", Edisi Ketujuh, Erlangga, Jakarta, 2006.

Kreitner, Robert. dan Kinicki, Angelo, "Perilaku Organisasi", Edisi Pertama, Salemba Empat, Jakarta, 2003.

Luthans, F, "Organizational Behavior", Tenth Edition, McGraw-Hill, New York, 2005.

Mulyasa, "Menjadi Kepala Sekolah Profesional", PT Remaja Rosdakarya, Bandung, 2004. 
Mulyasa, Manajemen Berbasis Sekolah Konsep, Strategi dan Implementasi, PT. Remaja Rosdakarya, 2004.

Riani, Asri Laksmi, "Budaya Organisasi”, Graha Ilmu, Yogyakarta, 2011.

Robbins, Stephen, "Organizational Behaviour", Tenth Edition, Alih Bahasa Drs. Benyamin Molan, PT. Macanan Jaya Cemerlang, Jakarta, 2003.

Rohiat, "Manajemen Sekolah Teori Dasar dan Praktek", Refika Aditama, Bandung, 2009.

Safri Nur Mantu, "Manajemen Sumber Daya Manusia \& Produktivitas", Rineka Cipta, Jakarta, 2007.

Santoso, Singgih, "Mengolah Data Statistik Secara Profesional", PT. Alex Media Komputindo, Jakarta, 2001.

Sedarmayanti,

Pengetahuan "Dasar-Dasar Manajemen Perkantoran", Mandar Maju, Bandung, 2001.

Sulistyaningsih, Ambar Sari Dewi dan Yani Tri Wijayanti, "Pengaruh Budaya Organisasi Terhadap Kinerja Karyawan UIN Sunan Kalijaga Yogyakarta", Jurnal Sosiologi Reflektif, Volume 6 Nomor 2, UIN Sunan Kalijaga, 2012.

Suryana, "Kewirausahaan, Pedoman Praktis, Kiat dan Proses
Menunju Sukses", Edisi Revisi, Salemba Empat, Jakarta, 2003.

Susanto, AB, "Budaya Perusahaan: Seri Manajemen Dan Persaingan Bisnis", Cetakan Pertama, Elex Media Komputindo, Jakarta, 1997.

Sutrisno, Edy, "Budaya Organisasi," Kencana Prenada Media Group, 2010.

Suyadi Prawirosentono, "Manajemen Sumberdaya Manusia

Kebijakan Kinerja

Karyawan", BPFE, Yogyakarta: 2008.

Udan Biantoro, "Pengaruh Praktek Manajemen Sumber Daya Manusia Terhadap Budaya Organisasi dan Kinerja Perusahaan", Disertasi Universitas Airlangga, 2002.

Undang-Undang RI Nomor 38 Tahun 1999 tentang Pengelolaan Zakat. Jakarta: Lembaran Negara Republik Indonesia Tahun 1999 Nomor 164.

Undang-Undang RI Nomor 23 tahun 2011 tentang Pengelolaan Zakat.

Wirawan, "Evaluasi Kinerja Sumber Daya Manusia", Salemba Empat, Jakarta. 2009.

Zainuddin M, "Metodologi Penelitian bidang ilmu Kefarmasian dan Kesehatan AUP", Surabaya, 2012. 